Pak. j. sci. ind. res. Ser. B: biol. sci. 2019 62B(1) 61-66

\title{
Review
}

\section{Importance of Herbal Plants in the Management of Urolithiasis}

\author{
Muhammad Jamila, Muhammad Mansoor ${ }^{a *}$, Noman Latif ${ }^{a}$, Sher Muhammad ${ }^{b}$, \\ Jaweria Gull ${ }^{c}$, Muhammad Shoab ${ }^{d}$ and Arsalan Khan ${ }^{\mathrm{e}}$ \\ ${ }^{a}$ Arid Zone Research Centre (PARC), Dera Ismail Khan, KPK, Pakistan \\ ${ }^{b}$ National Agricultural Research Center, Islamabad, Pakistan \\ 'Department of Biotechnology, Shaheed Benazir Bhutto University, Sheringal, Dir, Pakistan \\ ${ }^{\mathrm{d}}$ Rehman Medical Complex, Peshawar, KPK, Pakistan \\ ${ }^{\mathrm{e}}$ FMD Research Centre, Veterinary Research Institute, Peshawar, KPK, Pakistan
}

(received April 21, 2016; revised May 15, 2017; accepted June 23, 2017)

\begin{abstract}
Medicinal plants have been known for millennia and are highly esteemed across the world as an abundant source of therapeutic agents for prevention of various ailments. Today large number of population is suffering from urinary calculi, kidney stone and gall stone. Stone disease has gained increasing relevance as a consequence to changes in living conditions, due to malnutrition and industrialization. Changes in incidence and prevalence, the occurrence of stone types and stone location, and the way in which stone removal are explained. Therapeutic plants (Armoracia lopathifolia, Cassia fistula, Diospyros melaoxylon etc.) are being used from centuries because of its safety, efficacy, ethnical acceptability and less side effects when compared with synthetic drugs. The present review deals with options to be followed for the potential of medicinal plants in stone dissolving activity.
\end{abstract}

Keywords: medicinal plants, traditional medicines, urolithiasis

\section{Introduction}

Urolithiasis or nephrolithiasis is the oldest and endemic unpleasant urological disorder (Gilhotra and Christina, 2011). Urolithiasis or nephrolithiasis are generally known as stone formation in virtually any part of the urinary system such as, ureters, urinary bladder, kidneys and urethra and it is the third widespread disorder in urinary tract (Vidhya et al., 2013). Urinary stones are generally induced by bacterial infection while kidney stones are formed because of physicochemical or hereditary derangements resulting in super saturation of the urine with stone forming salts or, less commonly, from repeated urinary tract infections with urease producing bacteria like Pseudomonas aeruginosa, Proteus vulgaris, Enterobacter spp., Staphylococcus epidermitis, Serratia spp. and Staphylococcus aureus (Alok et al., 2013). Stone formation is a complicated process which occurs because of the successive physicochemical occurrences such as excellent saturation, growth, nucleation, retention and aggregation within the renal tubules (Yadav et al., 2011).

*Author for correspondence;

E-mail: joyadkpk@googlemail.com
Renal calculi can be broadly categorized in significant organizations: tissue connected and unattached. Connected calculi are mainly included by using calcium oxalate monohydrate (COM) renal calculi, with a detectable connection site to the renal papilla and essentially as well as a middle located near the connection website (concave area) and notably striated concentrically laminated peripheral layers. Unattached calculi, without detectable website of connection to papilla, are developed in renal cavities of low or reduced urodynamic efficacy and might showcase numerous composition and structures (Kuo et al., 2003; Grases et al., 2002).

Health professionals typically do not treat kidney stone, they just medicate the ache before the stones released out of the body. Vegetarian food programme, heavy on herbal products and drinks, may be helpful inside the cure and prevention of kidney stone. Therefore, the first-rate manner to save lots of kidney stone is to drink lots of water and have a vegetarian eating regimen excessive in magnesium. The typical pills used to save urolithiasis are not powerful in every sufferer, and lot of them have unfavorable effects therefore stop their permanent use. The modern day management of 
urolithiasis with open up renal surgery is not unusual and frequently used most reliable because that introduction of extracorporeal surprise wave lithotripsy (ESWL) which includes almost end up being the standard way of postponing off kidney stones. However, further to the irritating effect of shockwaves, continual residue stone fragments and the opportunity of contamination shows that ESWL can also motive severe renal injury, a lesser in renal feature and growth in stone recurrence. Hence, the hunt for antilithiatic pills to be powerful devoid of side effects from herbal resources has received huge capacity.

In the present article, a strive has been designed to emphasize on powerful herbs used in treatment for urinary stones. Herbs and natural tablets have created interest to some of the humans using its clinically examined results like adaptogenic, immuno-modulation, and antimutagenic. Additionally, the overuse of artificial capsules, which results in higher prevalence of destructive drug reactions, has inspired humans to return to nature for secure remedies. The origins, consistent with many, can be sourced to the industry fitness business enterprise's Canberre Convention in 1976, which marketed the idea of 'standard' prescription drug treatments for the growing countries. The trouble of urinary stones or calculi is an extremely historical one and many remedies have been used by people of different age groups in which stones are identified in all parts of the urinary system, the kidney, the ureters and the urinary bladder and can range significantly in size. Weight-reduction plan containing low levels of inferior exceptional proteins and high consumption of animal proteins might augment the chance of stone formation. The incident of urolithiasis is very common in northern areas of Pakistan when compared with Bangladash. It's far speculated that higher incident may be because of whole wheat diets. People living in rocky regions, wherein the local climate is warm and dry, appear to more prone to urinary calculi sickness. Treatment of urinary tract stones was revolutionized with the introduction of ESWL in the 1980s that resulted in $68-86 \%$ treatment succession of upper urinary tract stones which are treated on the basis of the size, type and location of the stone (Sarrafchi et al., 2016; Havagiray et al., 2010).

Usage history of medicinal plants prove them harmless than synthetic drugs (Nasri and Shirzad, 2013) that is why main focus of today's research is drug discovery from medicinal plants (Mohsenzadeh et al., 2016).
Various studies had demonstrated efficacy of medicinal plant extracts on kidney and urinary tract disorders (Gupta and Chaphalkar, 2016).Hayatdavoudi et al. (2016) evidenced that Kurd tribes treated kidney stones in Abdanan and Dehloran districts of Ilam Province, Iran using Alhagi persarum Boiss \& Buhse and Rubia tinctorum, Linum usitatissimum L., Tribulus terrestris L., Prunus cerasus L. and Foeniculum vulgare Mill.

Mechanism of stone formation. (Available from: $\mathrm{https//www.healingrosacea.com/urinary-stone-diseases/}$ 2), (Fig. 1).

Review of literature. Anand et al. (1994) made a comprehensive research on antiurolithiatic activity of Tribulus terrestris and Crateva nurvala in albino rats. The effective constituent isolated from Crateva nurvala was lupeol and it was thoroughly researched. Antiurolithiatic activity of lupeol was evaluated in rats by

Age, Profession, Nutrition, Climate, Inheritance, Sex, Mentality, Constitutions, Race

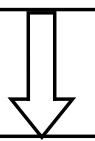

Abnormal renal morphology, Disturbed urine flow, Urinary tract infection, Metabolic abnormalities, Genetic factors

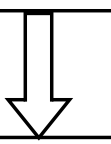

Increased excretion stone forming constituents, Decreased excretion of inhibitors of crystallizations

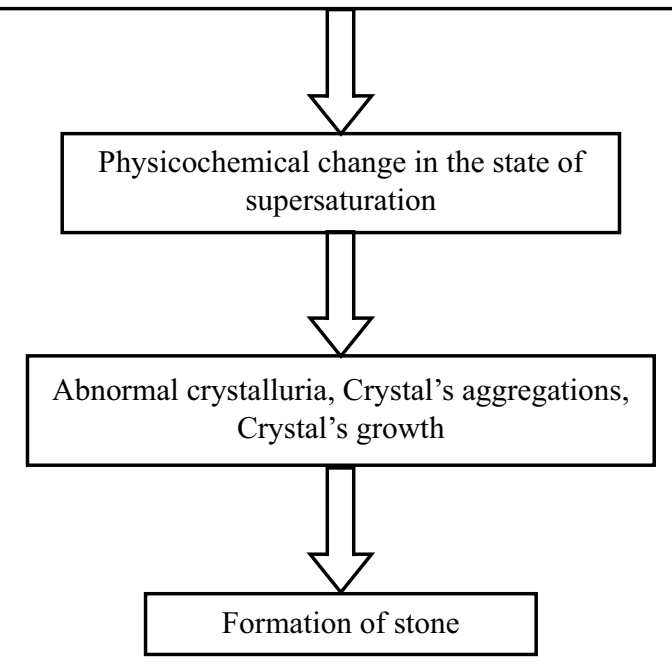

Fig. 1. Mechanism of stone formation. 
observing the weight of the stone, biochemical examination of serum and urine and histopathology of bladder and kidney. Lupeol not only prevented the forming of vesicle calculi but also reduced the size of the existing stones. They have concluded that lupeol have significant antiurolithiatic activity. Atmani et al. (2003) had experienced that Hibiscus sabdariffa Linn. has curative influence on stone formation induced by ethylene glycol. Joyamma et al. (2003) experienced that Mimosa pudica have good antiurolithiatic property. Ravindra et al. (2006) made a report on Moringa oleifera root in the management of renal calculi (Kokate et al., 1996; Seftel et al., 1990). Bahuguna et al. (2009) discovered that Jasminum auriculatum flowers have effective antiurolithiatic activity. The result of this plant on calcium oxalate nephrolithiasis has been analyzed in male albino rats. Ethylene glycol feeding led to hyperoxaluria as well as increased renal excretion of calcium and phosphate. Supplementation with alcoholic and aqueous extract of Jasminum auriculatum flowers significantly reduced the elevated urinary oxalate significantly, showing a regulatory action on endogenous oxalate synthesis. The increased deposition of stone forming constituents in the kidneys of calculogenic rats were also reduced by this extract treated groups. The effect that shows the flowers of Jasminum auriculatum is endowed with antiurolithiatic activity. Jarald et al. (2011) made a comprehensive research work on Unex for its antiurolithiatic property. The study mainly focused to judge the potency of Unex capsule on albino rats as a preventive agent resistant to the development of kidney stones. Activity of Unex capsule was researched using the ethylene glycol induced urolithiasis model and the study work shows that Unex capsule restored the urine $\mathrm{pH}$ to normal, and increased the urine volume significantly.

Gilhotra et al. (2011) made a report on the result of Rotula aquatic on ethylene glycol induced urolithiasis in rats. The alcoholic extract reduced the oxalate, calcium and phosphate in urine. In addition, it increased the urine volume, reducing the tendency for crystallisation. Anbu et al. (2011) made a study on antiurolithiatic activity of ethyl acetate root extract of Ichnocarpus frutescens using ethylene glycol induced method in rats. Supplimentation with ethyl acetate draw out of Ichnocarpus frutescens significantly reduced the increased urinary oxalate, showing a regulatory action on endogenous oxalate synthesis. The increased deposition of stone developing constituents in the kidneys of calculogenic rats were also decreased by this extract cured groups. The final result that the root of Ichnocarpus frutescens is endowed with antiurolithiatic activity. Ahmadi et al. (2012) studied effects of Alcea rosea root extract as a preventive and curative agent in ethylene glycol induced urolithiasis in rats. Regarding their research idea, Alcea rosea demonstrated a beneficial impact in protecting against and eliminating calcium oxalate deposition in the kidney of rat. This effect is possibly due to diuretic and anti-inflammatory effects or occurrence of mucilaginous polysaccharides in the plant. It could also be related to decrease of urinary concentration of stone-forming constituents. Suganya et al. (2012) made a research work on formulation and analysis of capsule containing poly herbal ingredients as an antiurolithiatic agent. Pre-formulation, formulation and in process quality control tests have been completed and the product was significant in nature (Kulkarni, 2009; Patwardhan et al., 1990).

WHO has approved the utilization of traditional drugs as part of its health programmes. According to a WHO survey, $80 \%$ of the populace surviving in developing countries rely almost exclusively on traditional medicines for primary health care needs i.e., in all the system of traditional medications, plants play a significant role and constitute its back bone. There are many possibilities available in the management of uretheral stones. Treatment selection will depends on stone size, composition and location, efficacy of every modality and associated morbidity, equipment available, physician skill, patient health preference and finally its costs. In many cases, the management of urolithiasis is combined with surgical and medical approach using percutaneous nephrolithotomy (PCNL), extracorporeal shock wave lithotripsy (ESWL) and antibiotics. These treatments tools are relatively costly, painful and require expert hands and availability of appropriate equipment. For the treatment of larger renal stones they are effective but recurrence rate are high and having their own side effects. Endoscopic stone removal and extracorporeal great shock wave lithotripsy (ESWL) brings about traumatic ramifications of shockwaves; persistent residual stone fragments and possibility of infection, very few of literatures suggest that ESWL may cause traumatic renal injury, decrease in renal function and increase in stone recurrence (WHO, 1998). Allopurinol, Cystone etc. are few drugs used in the treatment of renal calculi but these drugs are experiencing their own side effects. It has given rise to activation in the 
Table 1. Lists of plant drugs used in kidney stone, gall stone, urinary calculi (Prachi et al., 2009; Nidal, 2005)

\begin{tabular}{|c|c|c|c|c|}
\hline \multicolumn{2}{|c|}{ S.No. Botanical names } & \multirow{2}{*}{$\begin{array}{l}\text { Common name } \\
\text { Camels thorn }\end{array}$} & \multirow{2}{*}{$\begin{array}{l}\text { Part use } \\
\text { Roots }\end{array}$} & \multirow{2}{*}{$\begin{array}{l}\text { Used } \\
\text { For kidney pebbles and Sands }\end{array}$} \\
\hline 1. & Alhagi mannifera (Leguminosae) & & & \\
\hline 2. & Armoracia lopathifolia (Brassicaceae) & Horse radish & Seeds & Diuretic, Kidney Stones \\
\hline 3. & Aerva javanica (Amaranthaceae) & No Common name & Seed heads & Herb Diuretic, Purgative, Demulcent \\
\hline 4. & Aerva lanata (Amaranthaceae) & Gorkhabundi & Leaves & Cough, Sorethroat, Diabetes, Lithiasis \\
\hline 5. & Ammannia baccifera (Lythraceae) & Dadamari, & Root & $\begin{array}{l}\text { Ringworm, Parasitic skin affection, Anti-typhoid, } \\
\text { Anti-tubercular properties }\end{array}$ \\
\hline 6. & Arctostaphylos ura ursi (Asteraceaer) & Bearberry & Fruits & Diuretic, Diaphoretic, Gout, Skin affection \\
\hline 7. & Ascyrum hypericoides (Asclepidaceae) & Ascus & Root/Leaves & Emetic and Catharatic \\
\hline 8. & Asparagus racemosus (Liliaceea) & Satavar & Root & Herb tonic, Diuretic, Galactagogue \\
\hline 9. & $\begin{array}{l}\text { Abutilon indicum (L.) Sweet } \\
\text { (Malvaceae) }\end{array}$ & Indian Mallow & $\begin{array}{l}\text { Seed \& } \\
\text { Leaf extract }\end{array}$ & Extract is given for urinary disorder \\
\hline 10. & Abutilon indicum (L.) (Malvaceae) & Indian Mallow & Leaves & Juice taken twice daily for two weeks \\
\hline 11. & Aegle marmelose (L.) (Rutaceae) & Wood apple, Bael & $\begin{array}{l}\text { Leaves and } \\
\text { fruit }\end{array}$ & $\begin{array}{l}1 \text { spoon of Fruit pulp powder is taken orally with } \\
\text { coconut milk for } 14 \text { days to dissolve kidney stones }\end{array}$ \\
\hline 12. & $\begin{array}{l}\text { Amaranthus spinosus (L.) } \\
\text { (Amaranthaceae) }\end{array}$ & Spiny amaranth & Root or plant & 1 cup of whole plant is taken \\
\hline 13. & $\begin{array}{l}\text { Amaranthus viridis (L.) } \\
\text { (Amaranthaceae) }\end{array}$ & $\begin{array}{l}\text { Slender Amaranth, } \\
\text { Green Amaranth. }\end{array}$ & All parts & Given in kidney stone \\
\hline 14. & Argemone maxicana (L.) (Papaveracea) & Slender Amaranth & Root & Root powder is given for burning urination \\
\hline 15. & Ageratum conyzoides (L.) (Asteraceae) & Goat Weed & Leaves & Leaf extract is given twice a day \\
\hline 16. & $\begin{array}{l}\text { Amaranthus caudatus (L.) } \\
\text { (Amaranthaceae) }\end{array}$ & Love-lies-bleeding & Leaves & Extract is given in kidney stone \\
\hline 17. & Asphodelus tenuifolius (Cav.) (Liliaceae) & Weed of fields & Leaves & Decoction of leaves \\
\hline 18. & Apium graveolens (Apiaceae) & Lavender & Flowers & Decrease cholesterol level, Condiment. \\
\hline 19. & Barbarea vulgaris (Brassicacaea) & Rocket & Roots, Leaves & For kidney stone \\
\hline 20. & Berginia ligulata (Saxifragaceae) & Pasanabheda & Rhizomes & Astringent, Diuretic, Lithontriptic \\
\hline 21. & Bridolia montana (Euphobiaceae) & Chikitsa silianam & Bark & Bark Astringent, Anthelminetic \\
\hline 22. & Beta vulgaris & Sugar beet & Rhizomes & $\begin{array}{l}\text { Daily two glass of rhizomes juice is given in } \\
\text { kidney stone }\end{array}$ \\
\hline 23. & Bombex ceiba (L.) (Bombacaceae) & Cotton tree & Stem and bark & Given for urinary problems \\
\hline 24. & Borhaavia difffusa (Nyctagenaceae) & $\begin{array}{l}\text { Hogweed, } \\
\text { Punarnava }\end{array}$ & Root & $\begin{array}{l}\text { Root decoction is given daily for one month in } \\
\text { kidney stone }\end{array}$ \\
\hline 25. & Blumea balsamifera (Asteraceae) & Sambong & $\begin{array}{l}\text { Flowering } \\
\text { plant }\end{array}$ & $\begin{array}{l}\text { Diuretic, common cold, urolithiasis expectorant, } \\
\text { an anti-diarrheal }\end{array}$ \\
\hline 26. & Capsella Bursa-pastori (Brassicaceae) & Shepherd's-purse & Entire plant & Diuretic, For bladder \& kidney spasm \\
\hline 27. & Cucumis sativus (Cucurbitaceae) & Cucu & Leaves & Kidney stones, Emollient \\
\hline 28 . & Caesalpinia huga (Caesalpinioceae) & Nicker nut & Root & Root Diuretic, Lithontriptic \\
\hline 29. & Citrus japonica (Rutaceae) & Celery & Whole plant & Antispasmodic, Eczema \\
\hline 30. & Celosia argentla (Amararanthacea) & Plumed cockscomb & Leaves/Stem & Diarrhoea, Eye troubles, Sore mouth \\
\hline 31. & Chelidonium majus (Papaveraceae) & Chel & Leaves & Diuretic, Antispasmodic, bitter \\
\hline 32. & Cassia fistula (L.) (Caesalpinioideae) & Golden shower tree & Fruit & $\begin{array}{l}\text { Fruit powder is given with water for } 3-4 \text { month to } \\
\text { expel the kidney stone }\end{array}$ \\
\hline 33. & Ceropegia bulbos (L.) (Asclepidaceace) & Caudiciform & Tubers & $\begin{array}{l}\text { Decoction of tubers is used to remove urinary } \\
\text { bladder stone }\end{array}$ \\
\hline 34. & $\begin{array}{l}\text { Chenopodium album (L.) } \\
\text { (Chenopodiaceae) }\end{array}$ & Lamb's Quarters & Leaves & Coked leaves is given in urinary trouble \\
\hline 35. & Coculus hirsutus (L.) (Menispeermacea) & Cocculus Indicus & Leaves & Leaf dried powder is given during burning urination \\
\hline 36. & $\begin{array}{l}\text { Corbichonia decumbens (Forrsk.) } \\
\text { (Molluginacae) }\end{array}$ & Forssk & Leaves & Crushed leaves given orally \\
\hline 37. & Costus speciosus (Koen.) (Costaceae) & Keukand & Tubers & Decoction of tubers orally for stones \\
\hline 38. & Cynodon dactylon (L.) (Poaceae) & Dog's tooth grass & Root & Root decoction is given in case of urolithiasis \\
\hline 39. & Chimaphila numbellata(Cruciferae) & Prince's pine & Flower & Diuretic, Expectorant, Stimulant \\
\hline 40. & Curcuma longa (Zingiberaceae) & Haldi & Rhizome & Diuretic, Choleretic, Hepatoprotective \\
\hline 41. & Desmodium styracifolium (Papilionaceae) & Osbeck & Rhizome & Roots Emmenagogue, Stomachic \\
\hline 42. & Didymocarpus pedicellata & Stone Flower & Leaves & Lithontriptic \\
\hline 43. & Daucas carota (L.) (Apiaceae) & Wild carrot & Rhizome & $\begin{array}{l}\text { One glass juice is given midnight to remove } \\
\text { kidney stone }\end{array}$ \\
\hline
\end{tabular}


(Table 1 cont'd)

$\begin{array}{ll}\text { 44. } & \text { Digera Muricata (L.) (Amaranthaceae) } \\ \text { 45. } & \text { Diospyros melaoxylon (Rox) (Ebenaceae) } \\ \text { 46. } & \text { Dolichos biflorus (Leguminaceae) } \\ \text { 47. } & \text { Elettaria cardamomum (Zingiberaceae) } \\ \text { 48. } & \text { Equisitum arvense (Equisetaceae) } \\ \text { 49. } & \text { Fogonia bruguieri (Umbelliferae) } \\ \text { 50. } & \text { Ficus carica (Moraceae) } \\ \text { 51. } & \text { Garcinia pictoria (Guttiferae) } \\ \text { 52. } & \text { Gynocardia odorata (Flacourtiaceae) } \\ \text { 53. } & \text { Gomphrena celosioidest (Amaranthaceae) } \\ \text { 54. } & \text { Grewia flavescens (A.Juss) (Tiliaceae) } \\ \text { 55. } & \text { Hygrophila spinosa (Acanthaceae) } \\ \text { 56. } & \text { Lavendula officinalis (Lamiaceae) } \\ \text { 57. } & \text { Mentha piperita (Lamiaceae) } \\ \text { 58. } & \text { Mimosa pudica (Mimosaceae) } \\ \text { 59. } & \text { Ocimum (Labiatae) } \\ \text { 60. } & \text { Onosma bracteatum (Boraginaceae) } \\ \text { 61. } & \text { Olea europeae (Oleaceae) } \\ \text { 62. } & \text { Pavonia odorata (Malvaceae) }\end{array}$

64. Pedalium murea (Pedaliaceae)

65. Phy1llanthus emblica (L.) (Euphorbiaceae)

66. Phyllanthus fraternus (Webster.) (Euphorbiaceae)

67. Rosmarinus officinalis (Lamiaceae)

68. Rubia cordifolia (Rubiaceae)

69. Solanum surattence (Solanaceae)

70. Santalum album (Solanaceae)

71. Tectona grandis (Verbenaceae)

72. Theobroma cocao (Malvaceae)

73. Tamarind indica (Fabaceae)

74. Tinospora cordifolia (Wild L) (Menispermaceae)

75. Tribulus terrestis (L) (Zygophyllaceae)

76. Tridex procumbens (L.) (Asteraceae)

77. Tubiflora acaulis (L.F.) (Acanthaceae)

78. Urgina maritime (Asparagaceae)

79. Urtica dioica (Urticaceae)

80. Vernomia cineea (Compositae)

81. Zingiber officinale (Zingiberaceae)

82. Zea mays (Poaceae)
Digera Muricata

Digera Muricata

Horse gram

Cardamom

Horsetail

Fagonia

Fig

Tamal. Pers.

Coffee Plum

Gomphrena Weed

Sandpaper Raisin

Gokulakanta

Ginger

Peppermint

Touch-me-not

Holy Basil, tulsi

Sedge

Olive

Fragrant Swamp

Anise

Burra Gokhru

Gooseberry or

amla

Gulf leaf-flower

Rosemary

Madder or Indian

Madder

Yellow-Berried Nightshade

White sandal

Teak

Cacoa

Tamarindus

Guduchi

Puncture Vine

Coat buttons

Kuntze

Squill bulb

Stinging nettles

Little iron weed

Ginger

Maize
Leaves Once in a day for urinary complains

Fruit and bark Fruit is given in urinary disorders

Seeds Diuretic, Astringent, Tonic

Seeds Diuretic, Carmintive, Aromatic stimulant

Seeds Diuretic, Dropsy, Graval, Renal affection

Fruit Diuretic, Mildly carminative

Fruit, latex Destroy urinary \& gall Stone

Leaves Dropsical affection

Fruit Fish poision, Insecticidal, Skin aliments

Whole plant Juice is given twice a day for ten days

Root Decoction of root powder to stop bleeding in urine

Leaves Strongly Diuretic

Rhizomes Stop bleeding, Ant rheumatism

Entire herb Treatment in stone disease

Leaves Gravel, Urinary complaints

Leaves Stomachic, alexipharmac, antipyretic, antihelminitic

Leaves Tonic, Demulcent, Diuretic, Spasmolytic

Oil Treatment of kidney stone

Rhizomes, Antipyretic, Stomachic, Refrigerent, Dysentery

Leaves Mallow

Fruit

Fruits

Seed Powder

Antispasmodic, Diuretic, Treatment of kidney stones

Decoction of fruit is used for urinary complains

Given to avoid burning urination

Whole plant Plant extract is given orally for 3-4 day to dissolve the stones

Leaves Relive menstrual cramps, increase, urine flow, and reduce kidney pain

Leaves, Roots Antidysentric, Antiseptic, Deobstruent

Roots Root decoction is given for seven day

Oil

Wood Urinary discharge

Seed urinary tracts diseases

Fruits For kidney and gall stone

Stem Crushed stem to expel the stone

Leaves Used in treatment of kidney stone

Leaves Leaf paste is given for kidney stone

Leaves Leaf powder with water is given for urinary complains

Bulb leaves Diuretic

Roots Diuretic.

Leaves

Rhizomes

Seeds Oil

Anthelmintic, Diarrhoea

Stop bleeding, Ant rheumatism

Tassel
For bladder \& Kidney spasm. Given orally to expel the stone search for looking into natural resources demonstrating anti-urolithiatic activity. There is a tremendous progress in the field of medicine, but still there is no absolutely satisfactory drug for the treatment of renal calculi. Most patients still have to go through surgery to relieve this painful disease. Plants and other natural substances have been used as the rich source of medicine (Prachi et al., 2009; Nidal, 2005). All traditional civilizations have recorded therapeutic uses of plant in their own ethnobotanical texts. The list of drugs obtained from plants source is intensively extensive. Many remedies have been employed through the ages to take care of urolithiasis. A lot of the remedies have been extracted from plants and become useful, although the rationale behind their use is not medically established except for a few plants and some amazing composite herbal drugs (Sharma et al., 2001).

\section{Conclusion}

On the basis of the above discussion, it has been concluded that nature is better combinatorial chemistry and has possible answers to all or many diseases for 
mankind. Therapeutic plants play an essential role in stone diseases. The undesirable impact of the modern medication has recently diverted the interest of the individuals towards herbal medicines. To improve the acceptability and awareness among the people, there can be an urgent need to build up trust and faith for the safer indigenous system by establishing its validity in treatment for various diseases. Health care systems are more and more costly; therefore herbal medication systems must be introduced in our health care. Let us hope that in future natural basic products will be contending modern medications with added advantages of more basic safety and lower costs.

Conflict of Interest. The authors declare no conflict of interest.

\section{References}

Alok, S., Jain, S.K., Verma, A., Kumar, M., Sabharwal, M. 2013. Pathophysiology of kidney, gallbladder and urinary stones treatment with herbal and allopathic medicine: A review. Asian Pacific Journal of Tropical Diseases, 3: 496-504.

Gilhotra, U.K., Christiana, A.J.M. 2011. Antilithiatic activity of Kalanchoe pinnata Pers. on $1 \%$ ethylene glycol induced lithiasis in rats. International Journal of Pharmaceutical Sciences Review and Research, 10: $187-192$.

Grases, F., Costa-Bauzá, A., Ramis, M., Montesinos, V., Conte, A. 2002. Simple classification of renal calculi closely related to their micromorphology and etiology. Clinica Chimica Acta, 322: 29-36.

Gupta, A., Chaphalkar, S.R. 2016. Anti-inflammatory and immunosuppressive activities of some flavonoids from medicinal plants. Journal of Herbal Medicine and Pharmacology, 5: 120-124.

Havagiray, R., Shashi, A., Jain, S.K., Sabharwal, S.K. 2010. Herbal treatment for urinary stones. International Journal of Pharmaceutical Sciences and Research, 1: 24-29.

Hayatdavoudi, P., Khajavi, R.A., Rajaei, Z., Hadjzadeh, M.A. 2016. Renal injury, nephrolithiasis and Nigella sativa: a mini review. Avicenna Journal of Phytomedicine, 6: 1-8.

Kokate, C.K., Purohit, A.P., Gokhale, S.B. 1996. Textbook of Pharmacognosy. IV $^{\text {th }}$ edition, Pune, Nirali
Prakashan, India.

Mohsenzadeh, A., Ahmadipour, S.H., Ahmadipour, S., Asadi Samani, M. 2016. A review of the most important medicinal plants effective on cough in children and adults. Der Pharmacia Lettre, 8: 90-96.

Nasri, H., Shirzad, H. 2013. Toxicity and safety of medicinal plants. Journal of Herbal Medicine and Pharmacology, 2: 212.

Nidal, A.J. 2005. Medical plants utilized in Palestinian folk medicine for treatment of diabetes mellitus and cardiac diseases. Journal of Al-Aqsa University, 9: 2005.

Patwardhan, B.D. 1990. Search of Immunomodulatory agent - a review. Indian Drugs, 28: 56-63.

Prachi, N., Chauhan, D., Kumar, M.S. 2009. Medicinal plants of Muzaffar Nagar district used in treatment of urinary tract and kidney stone. Indian Journal of Traditional Knowledge, 8: 191-195.

Sarrafchi, A., Bahmani, M., Shirzad, H., RafieianKopaei, M. 2016. Oxidative stress and Parkinson's disease: New hopes in treatment with herbal antioxidants. Current Pharmaceutical Descriptions, 2: 238-246.

Seftel, A., Resnick, M.I. 1990. Metabolic evaluation of urolithiasis. Urologic Clinics of North America, 17: 159.

Sharma, P.C., Yelna, M.B., Dennis, T.J. 2001. Database on Medicinal Plants used in Ayurveda. vol. II, New Delhi, CCRAS, India.

Vidhya, G., Sumithra, G., Anandhan, R., Anand, G. 2013. Antiurolithiatic activity of Nardostachys jatamansi D C on modified lithogenic diet induced urolithiasis in rats. International Journal of Advances in Pharmaceutical and Genetic Research, 1: 5263.

Vijay, T.R., Rao, N.V.N., Babu, A., Sathish Kumar, M., Sharmila N.P., Reddy, B.S., Ramarao, N. 2013. Antiurolithiatic activity of methanolic extract of dried leaves of Glochidion velutnium using ethylene glycol induced rats. International Journal of Biology and Pharmaceutical Research, 4: 878-884.

Yadav, R.D., Alok, S., Jain, S.K., Verma, A., Mahor, A., Bharti, J.P., Jaiswal, M. 2011. Herbal plants used in the treatment of urolithiasis: A Review. International Journal of Pharmaceutical Research and Technology, 2: 1412-1420. 